i.e., that in the long run the balance of payments is equal to the trade surplus plus the surplus on the service account, a condition which is consistent with the zero balance on the capital account implied by long-run equilibrium.

\title{
References
}

Branson, William H., "The Dual Roles of the Government Budget and the Balance of Payments in the Movement from Short-Run to Long-Run Equilibrium", The Quarterly Journal of Economics, Vol. 9o, Cambridge, Mass., 1976, pp. 346--367.

Scarth, William M., "Fiscal Policy and the Government Budget Constraint under Alternative Exchange-Rate Systems", Oxford Econnmic Papers, N.S., Vol. 27, Oxford, 1975, pp. 10-20.

Steinherr, Alfred, "Economic Policy in an Open Economy under Alternative Exchange Rate Systems: Effectiveness and Stability in the Short and Long Run", Weltwirtschaftliches Archiv, Vol. I I I, I975, Pp. 24-5I.

Turnovsky, Stephen J., "The Dynamics of Fiscal Policy in an Open Economy", Journal of International Economics, Vol. 6, Amsterdam, 1976, pp. II5-I42.

\section{Economic Policy in an Open Economy: A Reply}

By

Alfred Steinherr

Tn my r975 paper I had side-remarked that stationary equilibrium is improbable with existence of foreign debt. This view is challenged by Petith. The difference arose because he defines savings, and rightly so, in terms of disposable income whereas I defined savings in terms of domestic production. According to my definition domestic production is equal to domestic consumption in the stationary state; in the alternative case called the correct solution by Petith, consumption is not equal to domestic praduction. For example, a long-run trade surplus, used to finance interest payments on net foreign debt, implies that consumption falls short of domestic production. Is this a reasonable characterization of stationarity? I think not. There is no reason why in a stationary state domestic wealth is not such as to allow all of domestic production being consumed. 